\title{
Levels of Analysis in International Relations and Regional Security Complex Theory
}

\author{
Fakhreddin Soltani (Corresponding author) \\ Department of Politics and Government \\ Faculty of Human Ecology, Universiti Putra Malaysia (UPM) \\ 43400, Serdang, Selangor, Malaysia \\ fakhreddinsoltany@gmail.com
}

Saeid Naji

Governor of Baharestan County, Tehran, Iran

Email: Naji_Saeid@yahoo.com

\author{
Reza Ekhtiari Amiri \\ Faculty of Law and Political Science, \\ University of Mazandaran, Main Campus of the University (Pardis) \\ Air Force Street, Babolsar, Iran \\ Email: ekhtiari2002@gmail.com
}

Accepted: November 17, 2014

Doi:10.5296/ jpag.v4i4.6973 URL: http://dx.doi.org/10.5296/ jpag.v4i4.6973

\begin{abstract}
Levels of Analysis is related to the explaining of causes of phenomenon (Buzan, 1995). The coming to the fore of levels of analysis in international relations was the result of the behavioral movement during the 1950s that was attempting to apply methodology of natural sciences in social sciences. Before that, traditional approaches were dominant, and they were more oriented towards history and law. The works of Kenneth N. Waltz, Morton A. Kaplan, and J. David Singer have had major roles in bringing levels of analysis into international relations (Buzan, 1995). Since then, the works of Barry Buzan and Ole Wæver have added
\end{abstract}


the level of regional analysis to International Relations studies. This article reviews the three main levels of analysis and also explains the regional level of analysis in international relations.

Keywords: International relations, levels of analysis, Copenhagen School, Regional Security Complex.

\section{Introduction}

The behavioral movement of the 1950s led to epistemological debate between two primary "atomistic" and "holistic" approaches (Buzan, 1995). These two approaches were commonly known as reductionist and systemic since the publishing of Kenneth Waltz's book entitled "Theory of International Politics" (Waltz, 1979). According to the atomistic/reductionist approach, studying component parts of the system makes one able to improve understanding of the phenomenon while holistic/systemic approach emphasizes that the whole is always more than just component parts of the system. In other words, construction of the parts is shaped by structures embedded in the system (Buzan, 1995).

Waltz in his book "Man, the State and War (Waltz, 1959) introduced three aspects of: human nature, the nature of states and the nature of the international system, as being causes of war. In other words he explained three levels of analysis including the individual, the unit or state, and the system. All three levels act under anarchical structure of international system. Among the three aspects, Singer and Kaplan favored unit level while Waltz favored the system level. System is "a set of units interacting within a structure". The system approach is the most influential one in studying levels of analysis in international relations.

\section{Levels of Analysis}

Two levels of analysis are obvious in international relations; unit level which is favored by Singer, and structure of system, favored by Waltz (Waltz, 1979). David Singer introduced two levels of analysis including the international system and the national sub-systems (Singer, 1961). According to Singer, international system is the most comprehensive level of analysis that encompasses interactions of system alongside component parts of the system. International level of analysis helps in understanding patterns of interaction and also helps to make generalizations and therefore predictions. In other words, the systemic level of analysis creates the opportunity to study international relations in the whole. He argues that the main weakness of systemic level is its lack of details. In other words, in systemic approach, students have no choice but to ignore some details in favor of studying the whole. He argued that the strengthening characteristic of systemic orientation is its ability of prediction. Behaviors of actors, in systemic approach, can be predicted generally in terms of pressure structure of system force (Singer, 1961).

While systemic approach emphasized generality of behavior of actors, national level of analysis insists on specific sorts of goals the nation follows. At national level, internal and external factors of behavior are distinguished, and therefore the effects are different from system level. Though systemic level provides a more comprehensive picture, Singer argues that sub-systemic or actor-oriented system is more fruitful because of its richer details. But he believes that both levels of analysis offer a similar degree of prediction. In the end, he mentions that study of international relations is not limited to just national and systemic levels, and that there may be other available and perhaps, even more fruitful ones (Singer, 1961).

Unit level of analysis was also favored by Morton Kaplan, especially in a typological study of 
international systems in his book "System and Process in International Politics" (Kaplan, 1957). He introduced patterns of power distribution or configuration of alliances whereby he explained behavior of states in international system according to these patterns (Buzan, 1995). Morton Kaplan (Kaplan, 1957) introduces six $^{1}$ models of international system that all are unit-based analysis and the characteristics of the system are determined by prevailing units.

\section{Copenhagen school}

Since 1979, when Waltz's Book "Theory of International Politics" was published, the system approach has been the most prevailing unit of analysis in studying international relations. But in some cases, the system level was not able to explain the causes of the events. According to Copenhagen school, system level as viewed by neorealism has three weaknesses in security studies. First, it overestimates the importance of global polarity and causes and therefore it overlooks regional effects. Second, neorealism emphasizes too much on military security and on the state. And thirdly, overemphasized objectivist approach of neorealism makes it overlook social construction of regions and security (Buzan \& Wæver, 2003).

The most distinctive contributions of the Copenhagen School have been the concepts of societal security and securitization which led to the Regional Security Complex Theory of Barry Buzan and Ole Wæver (Buzan \& Hansen, 2009). Societal security is defined as "the ability of a society to persist in its essential character under changing conditions and possible or actual threats" (Wæever, Buzan, Kelstrup, \& Lemaitre, 1993). Collective identities such as religions and nations are referent objects of security studies in societal sector that are independent of the state. In this perspective, language, religion, ethnic identity and cultural tradition need to be protected against cultural imports. Threats in societal sector may have internal or external sources and any one of the sources may be transformed into another one (Stivachtis, 2008).

The securitization theory argues that security is socially and inter-subjectively constructed. According to the theory, political actors or securitizing ones label things as threat, or security affair to legitimize their goals - and the tools of achieving them. The main goal of securitization theory of the Copenhagen School is to understand who, why and under what conditions issues get securitized (Timchenkova, 2010). Ontologically, society, or in other words, societal security, instead of state, is the referent object for securitization theory. In this regard, identities of states are accommodated as the main source of study in international relations (Buzan \& Hansen, 2009). Egotistical attitudes of the actors cause them to securitize their issues against each other. In other words, different actors understand nature of survival and threats differently. An issue becomes a security issue because the issue is presented as such a threat. Therefore, securitization is essentially an intersubjective process. Securitization process can be institutionalized through being persistent or recurrent. Military issues are examples of institutionalized securitization (Buzan, Wæver, \& Wilde, 1998), hence, Copenhagen is more at middle level of analysis rather than individual and system levels (Buzan \& Wæver, 2009).

\section{Regional Level of Analysis}

As mentioned, the concepts of societal security and securitization led to Regional Security Complex (RSC) theory. RSC attempts to explain how regional level of analysis provides better explanation of phenomena in international relations. The main concept in regional level of study, as Buzan and Wæver put it, is complex security that refers to the situation in which

\footnotetext{
${ }^{1}$ Balance of power in which six or seven units prevail in the system (related to Western world in the eighteenth and nineteenth centuries); loose bipolar system in which two national actors with greater power than the others dominate the system and other units group around the two major actors in loose blocs (some of them may be neutral); tight bipolar system in which units are not permitted to be neutral and therefore have to be ally of one specific major power; universal international system in which the Universal Actor (e.g., United Nations) is powerful enough to prevail in the system and prevent war among units though units retain their independence within the framework of the Universal Actor; hierarchical international system in which there is only one Universal Actor and other units lack independence; and finally, unit veto system in which any actor or unit possesses weapons (nuclear ones) that can destroy all others before being destroyed itself, no matter how powerful the other units.
} 
security issues of states are inter-connected to each other in a way that is not possible to separate them reasonably. The main idea of the complex security has come from their earlier book in 1988 in which they defined it as an interlinked process of securitization and de-securitization of states (Buzan et al., 1998).

The idea of complex security led to their next book "Regions and power: the Structure of International Security", to provide a level of analysis for a new era in international relations. Buzan and Wæver (Buzan \& Wæver, 2003) introduced regional level of security as a prominent tool for studying international politics especially since the end of the Cold War. The main idea of this book is that local powers have more room for maneuvering due to end of bipolarity and lack of superpower rivalry. They argue that the sole superpower (United States) and other great powers (China, EU, Japan, and Russia) are not willing to intervene in security affairs outside their own regions because their domestic capabilities are not enough to engage militarily and undertake strategic competition in critical parts of the world. Therefore, they have no alternative but to leave local powers to deal with military and strategic issues within their own regions (Buzan \& Wæver, 2003).

According to them (Buzan \& Wæver, 2003), RSC theory enables scholars to get better understanding of new structure of international politics. RSC uses bounded territoriality and distribution of power in neorealism and securitization in the Copenhagen School. What makes it different from neorealism is that it rejects global level structure in neorealism and emphasizes regional level. In its analysis, patterns of amity and enmity are used as independent variables that determine the character of security relations. RSC has constructivist roots because it applies patterns of amity and enmity among states and hence interpretations of states are one of the determinant factors in regional level of analysis.

According to RSC level of analysis, a mixture of history, politics, and material conditions in every region forms specific patterns of security and insecurity. According to Buzan and Wæver, security is what states make according to patterns of amity and enmity and power relations in every RSC. Therefore, to them, there are four levels in forming of RSC: domestic conditions of the states of the region (including both strengths and weaknesses); state-to-state relations which form the RSC; region-to-region relationship especially with neighboring ones; and finally the role of global powers in RSCs.

Buzan and Wæver (2003) believe that RSC theory offers a proper basis for comparative studies in regional level and provides some powers of prediction. They argue that RSC as the fourth level of analysis is complementary to the neorealist perspective on system structure. Therefore security of states is not the sole level of analysis because every state puts itself at the center of security analysis. Also, global level, in any holistic sense, is far from reality because it can be applied specifically for superpowers only. But it is the regions that are the locus where actors link together and it also is the point where there is national and global security interplay.

\section{RSC Theory and the Role of Great and Super Powers}

RSC is the theory of security whose focus is on geographic factors. It emphasizes that regional level of study does not mean that the world is not state-centric, but it seeks to explain that states make more security interaction among neighbors than among states located in different areas. In other words, adjacency causes threats to travel more easily. Therefore, adjacency is the basis of forming interests in other areas of the world. Only superpowers have the capability of having wide-ranging interests over the whole planet. It is important to mention that the rule of adjacency is more applicable in security issues rather than economic ones (Buzan \& Wæver, 2003).

In every region, penetration of great powers occurs when regional rivalry invites them in for reasons such as balance of power. The presence of outside powers in the region or RSC links local and global security patterns. It is what happened between India and Pakistan, providing opportunity for presence of great powers in their RSC. Actually security patterns stem from indigenous factors of every RSC and outside powers cannot affect it except in unipolar 
system especially when rival states of the region all are dependent on the superpower.

There are two kinds of RSCs, namely "standard" and "centred". Standard RSC naturally is Westphalian, in which anarchic structure is the character of security complex. In standard RSC there are regional powers e.g., Iran, Iraq, and Saudi Arabia in the Gulf, India and Pakistan in South Asia and South Africa in Southern Africa. In every standard RSC, there might be one or more regional powers and therefore it might be unipolar or multipolar. But what makes unipolar standard RSC different from a centred one is that the security dynamics of the region are shaped through interactions among regional powers - not just by one of them as happens in centred ones. Actually the main element of security politics in standard RSC is interaction among regional powers on the basis of amity and enmity. They determine terms for other members of RSC and also for intervening of global powers.

If the member of RSC is a superpower or great power then the centred RSC gets formed. According to distribution of power, there are three main forms of centred RSCs. RSC centered by superpower for example United States in North America; centred by great power for example Russia in the CIS; and centred by regional power, for example India in South Asia (though Pakistan challenges it as regional power). Unipolarity alone in the region does not form centred RSC because the region might be unipolar but the security dynamics of the region is not determined by the unipolar power. In centred RSCs the present power determines security dynamics of the region. It is possible that standard RSCs may transform into centred ones or vice versa through changes that may happen in distribution of power. The similarity among these three forms of centred RSCs is the way security dynamics of the region is dominated. Misunderstanding these security dynamics may put countries in critical situations as what happened to United States in Vietnam and to Soviet Union in Afghanistan.

Two situations prevent forming of RSCs, which are called overlay and unstructured factors. Overlay refers to the situation in which an outside great power dominates the region militarily in order to pursue its interests. The presence of a great power stops local powers from forming their own security entities. Some examples are colonization of Africa, Asia, and Americas by European countries, as well as the situation in Europe during the Cold War. Unstructured security situation occurs in the region in which there is no local power to organize security patterns. In other words, their capabilities are so low that it makes them limited to their boundaries, or if there is any local power, the geographical insulation makes forming of regional security patterns difficult. These two conditions may amplify the effect of each other. Of course, it is important to mention that geographical insulation is an important factor even for capable actors. The South Pacific islands may be cited as an example of unstructured situation.

\section{Conclusion}

The RSC theory attempts to explain the post-Cold War period in which the global power structure shifted from $2+3$ (USA and the Soviet Union as superpowers + China, Japan, and the EU as great powers) during the Cold War to 1+4 (USA as superpower + Russia + China, Japan and the EU as great powers). The RSC theory, through focusing on geographical factors of security, tries to show how three (individual, unit, and system) levels of analysis are not enough to explain the post-Cold-War era.

The main assumption of the RSC is that the regional security autonomy is more applicable in post-Cold-War security order. According to the theory, regional level of analysis is more applicable for events of international politics. There are two RSCs, namely "standard" and "centered". Standard RSC follows the regularities of Westphalian security complexes in which regional powers form the character of security complexes in the region. Centered RSC is dominated by a superpower or a great-power member of the states in the region. Among them, the regions centered by either global power or through institutions are the most peaceful RSCs. 


\section{Al Macrothink}

\section{References}

Buzan, B. (1995). The Level of Analysis Problem in International Relations Reconsidered. In K. Booth \& S. Smith (Eds.), International Relations Theory Today. Cambridge: Polity Press.

Buzan, B., \& Hansen, L. (2009). The Evolution of International Security Studies. Cambridge: Cambridge University Press.

Buzan, B., \& Wæver, O. (2009). Macrosecuritisation and security constellations: reconsidering scale in securitisation theory. Review of International Studies, 35(2), 253-276.

Buzan, B., Wæver, O., \& Wilde, J. d. (1998). Security: A New Framework for Analysis. Colorado: Lynne Rienner Publishers.

Buzan, B., \& Weaver, O. (2003). Regions and power: the Structure of International Security. New York: Cambridge University Press.

Kaplan, M. (1957). A. System and Process in International Politics. In. New York: John Wiley \& Sons.

Singer, J. D. (1961). The Level-of-Analysis Problem in International Relations. World Politics, 14(1), 77-92.

Stivachtis, Y. A. (2008). International Migration and the Politics of Identity and Security. Journal of Humanities and Social Sciences, 2(1).

Timchenkova, T. (2010). Securitization of Migration: Securitizing identity through Words and Images. The Case of Chinese Migration to Russia. Central European University, Budapest, Hunfary.

Wæver, O., Buzan, B., Kelstrup, M., \& Lemaitre, P. (1993). Identity, Migration and the New Security Agenda in Europe, . New York: Palgrave Macmillan.

Waltz, K. (1959). Man, The State, And war. New York: Colombia university press.

Waltz, K. (1979). Theory of International Politics. New York: Random House. 